\title{
Potential of Micro-algae in Future Biofuels
}

\author{
Isha Bhansali, Hardik Pathak and Jebi Sudan**
}

Department of Plant Biotechnology, JECRC University, Jaipur, Rajasthan, India

*Corresponding author

\section{A B S T R A C T}

\begin{tabular}{l} 
Ke y w o r d s \\
$\begin{array}{l}\text { Microalage, } \\
\text { biofuels, } \\
\text { Cultivation } \\
\text { procedure, } \\
\text { Harvesting, } \\
\text { Environmental } \\
\text { applications }\end{array}$ \\
$\begin{array}{l}\text { Article Info } \\
\text { Accepted: } \\
\text { 12 December } 2020 \\
\text { Available Online: } \\
\text { 10 January } 2021\end{array}$ \\
\hline
\end{tabular}

\section{Keywords}

Microalage, biofuels,

Harvesting,

Environmental

Article Info

Accepted:

12 December 2020

Available Online:

Overabundance carbon impression is one of the major natural issues of this decade. The major concern is regarding the substitute source of energy as carbon emission is contaminating the environment. Among sustainable power sources, carbon unbiased biofuels from microalgae give off an impression of being a promising move towards manageability and cleaner powers attributable to its presence of high $\mathrm{CO}_{2}$-sequestering capacity, high lipid efficiency and being effectively cultivable in an open pond and waste, marine and saline water. Algae are viewed as the most promising asset for the up coming ages as the most sustainable feedstock. There is immense interest for using these algal growth as a potential source of energy by conversion the primary and secondary metabolites into beneficial products. These algal biofuels are considered as third era biofuels. The third era biofuels are the best option to the current circumstance since they have the potential to dispense with a large portion of the biological issues made by the utilization of non-renewable energy sources. Inspite of getting consideration during the recent couple of decades, the creation of microalgal biofuels isn't yet adequately practical to compete with conventional fuels based on petroleum as the harvesting and production of microagale biofuels is financially inadequate. This articles emphasises on different strategies for both biomass reaping and lipid extraction from microalgae accessible up until now which are cost effective. It also elaborates about the varied applications of micro algae in other ways.

\section{Introduction}

Marine algae including marine cyanobacteria, marine eukaryotic microalgae, and kelp, are the most senile member from the plant kingdom, that are found from the polar district to tropical zones and from supplement rich beach front oceans to oligotrophic vast sea. These marine algae are accountable for $40 \%-50 \%$ of photosynthesis on Earth( Falkowski et al., 1998). It is assessed that approximately of 50,000 species exist, yet just a set number, of around 30,000, have been examined and dissected.

Micro algae mostly require three foremost components for growth which consist of sunlight, water, and a carbon source. For the requirements of nutrients they rely on the aquatic habitats, and for the source of carbon they either seize $\mathrm{CO} 2$ from the atmosphere or feed on inorganic compounds and they efficiently produce approximately $50 \%$ of the atmospheric oxygen. Since they are 
considered to be extremely capable of utilising sunlight and carbon source for making organic compounds. There extreme capabilities of making high amount of oil yields and satisfactory lipid amount which is required for the biofuel production. Above that they also show high growth rate and have minimum land requirement in comparison to convectional land crop biofuel. Therefore since last decade biofuel production from microalage have been an area of extensive research as an alternate to convectional fuels like petroleum and diesel so that they can serve as third generation biofuel.

In recent times whole world approximately about $95-97 \%$ is dependent upon the direct combustion of biomass. The production of first generation biofuel are manufactured from consumable food materials majorally starch, sugar and oils. But the production of first generation biofuel is an an issue of debate due to "food versus fuel" dilemma as in another perspective it has been seen that this kind of biofuel production might hinder the global security of food. Hence another way of generation biofuel has to be devised.

The second generation biofuel were seen as an potential alternative to first generation biofuel. Since these are produced from non edible crops that are primarily derived from lignocellulosic feedstock for instance like wood, sludge, organic wastes etc. These biofuels bring a lot more plus points in comparison with the first generation since they don't rival food supplies and conventionally have better return and lower land necessities. Regardless of potential benefits the constraints of the first-and second generation biofuel is that they are dreadfully deficient to fulfill worldwide needs for biofuels because of, land accessibility and are environment affable. To overcome these demerits there was a shift towards third generation biofuel.
The third generation biofuel have received great attention as they are being generated from algae biomass. The third generation biofuels are viewed as a realistic approach that may vanquish the significant downsides associated with the first and second generation biofuels. Nonetheless, the positive outlook of algae based fuel formation that it in harmony with natural and social viewpoints but is has not been sufficient at present because of the high commercial production costs

The initial studies on microalge production have been commenced in 1950's under controlled production (Burlew 1953) The first large-scale culture of microalgae started in the early 1960s in Japan by Nihon Chlorella with the culture of Chlorella since then the advancement in microalgae production has been observed. The production of micro algae takes place in several steps

\section{Steps of biofuel production}

\section{Cultivation}

The major four classes of cultivation are:

- phototrophic

- heterotrophic

- Mixotrophic

- photoheterotrophic

\section{Photoauthotrophic Cultivation}

In this kind of cultivation micro algae uses sunlight as a sole imperativeness source and the sunlight is converted to chemical energy through photosynthesis. In phototrophic procedure, microalgae can be created in open ponds and photobioreactors.

Open lake development are the most established and least complex frameworks generally utilized for augment microalgae 
yield. These microalgae developing strategies have been in practice since the 1950s. Open pond development system, which are basically isolated reliant on their size, shape, and material used for advancement, way of unsettling, and tendency.

A prototypical raceway pond involves a closed circle oval channel, 0.25-0.4 m profound, open to the air, and blended in with a paddle wheel to course the water and forestall sedimentation to evade aggregation of poisonous or hindering compounds and to control improvement of microorganisms the ponds water is dislodged at regular intervals usually the water is flushed out in every two months.

Open pond process are less enumerate in plan and are more adaptable; but, they are limited by abiotic growth factors such as temperature, $\mathrm{pH}$, light force, and dissolved oxygen congregation. Above that there are various animals which can corrupt the lake and damage the microalgae. Additionally this method has obstructions in view of moderate cell improvement and low biomass production that incline sparse oil profit-making.

On the other hand photobioreactors require significantly more energy for building and during preparing contrasted with the expansion in profitability that they offer.

However the open pond frameworks appear to be supported for business development of microalgae at present because of their low capital costs but the closed frameworks that is photobioreactors offer better command over defilement, mass exchange, and other development conditions nevertheless in general photobioreactors or closed systems are expensive than open ponds.

\section{Heterotrophic Cultivation}

In this type only organic compounds are being used by micro algae as an energy source. The significant favourable circumstances related with heterotrophic development over phototrophic development are the acceptable control on cultivation strategy, termination of sunlight requisite, and ease of biomass harvesting.

Heterotrophic improvement additionally accord better oil profitability. As a result, this approach has gather amazing excitement when set side by side with other advancement techniques. Notwithstanding, heterotrophic microalgae culture is polluted easily that impacts the large scale manufacturing of microalgae.

\section{Mixotrophic cultivation}

Carrying out photosynthesis is the essential source of energy, although both organic compound and $\mathrm{CO} 2$ are fundamental or on the other hand it can be explained as that micro algae can live either autotrophically or heterotrophically, dependent upon the availability of organic compounds and sunlight. Hence mixotropic is a type of cultivation of micro algae in which both inoganic and organic carbons source are exploited for microlgae growth mixotrophic and photoheterotrophic production endure from probability of contamination and light prerequisites and therefore require creation of photobioreactor for enhancing that increases the capital and activity costs.

Thereafter, consequently there is a necessity for extra progression of advances with higher microalgae advancement rates, to improve the capacity of open air production and with a strong safe instrument for restricting the tainting chances in the mass scale microalgae production method. 


\section{Harvesting of micro-algae}

The financially potent harvesting of microalgae is viewed as the most troublesome zone of algal biofuel mass production and this isprobably the utmost critical factor which is restricting the mercantile usage of micro algae biofuel.

The cost of micro-algae gathering is exorbitant, due to the low mass proportions in the broth medium, while the cells regularly convey negative charge and overabundance algogenic organic matters (AOM) to keep their steadiness in the scattered state. Approximately it takes around 1-10 days to finish off one harvesting cycle. The significant strategies legitimately applied in the gathering of microalgae incorporate:

- centrifugation

- flocculation

- filtration and screening

- gravity sedimentation

- buoyancy

- Electrophoresis techniques.

The inclination of harvesting technique is reliant on the properties of microalgae, for instance density, size, the value of desired product.

\section{Centrifugation}

It has been experimentally observed that all types of produced microalgae could be separated efficiently and with the assistance of centrifugation (mohn 1988)

Further laboratory centrifugation experiments were performed on effluvium obtained from pond cultivationwhich indicated that around 80-90\% mic-roalgae can be recuperated in the time of $2-5 \mathrm{~min}$. Grima et al., in 2003 concluded that centrifugation is a favored technique for harvesting of microalgal biomass, particularly for creating broadened shell life concentrates for hydroponics.

Centrifugation being advantageous also has demerits as the micro algal cells are being aquatinted with high gravitational and shear forces by which the cell structure could be disrupted. Additionally centrifugation technique is not cost effective for micro algae separation. It is estimated that approximately the expense of energy, materials, maintenance and the servicing of centrifuge will might cost up to $25 \%$ of the overall cost of the production of micro algae.

\section{Flocculation}

Flocculation is a convoluted cycle that is impacted by varied cell properties for instance, cell surface properties, cell concentration, $\mathrm{pH}$ of the surrounding, ionic strength, and sort of flocculant(Schenk et al., 2008; Uduman et al., 2010). Inorganic synthetic concoctions are utilised in this approach for example, ferric, aluminium, and zinc salts, micro algae cells gradually sink to the base of the compartment once they get coagulated. The negative charge of micro algae is altered with the help of Cations, like $\mathrm{Al} 3+$ or Fe3+. Subsequently, the cells aggregate and tremendous flocs which are settled in the bottom aresegregated from the culture medium. In certain micro algae auto flocculation takes place. Auto Flocculation is a kind of flocculation which can happen naturally in few micro algal growth, and flocculationof micro algae may take place because of environmental pressure; changes in concentration of nitrogen, fluctuation of $\mathrm{pH}$ and dissolved oxygen.

\section{Gravity sedimentation}

Sedimentation can be depicted by Stokes' Law which assumes that sedimentation 
velocity is proportional to the square of the (Stokes') radius of the cells and the difference in density between the micro algal cells and the medium as demonstrated as follows:

\section{Settling velocity}

$$
\frac{2}{9} g \frac{r^{2}}{n}\left(\rho_{s}-\rho_{l}\right)
$$

Here;

$\mathrm{R}$ - is a cell radius $\eta$ is fluid dynamic viscosity

$\rho s$ and $\rho 1$ are the solid and liquid densities respectively

Seperating a feed suspension into a slurry with higher concentration and an effluent of significantly clear liquid that is in the process of gravity sedimentation solid liquid separation is done (Svarovsky 1979b). Sedimentation velocity is impacted by Density and radius of micro algal cells and the instigate the settling phenomena of suspended solids (Brennan and Owende, 2010) the density of microalgal is vital to ensure the proficiency of this method, nevertheless the reliability of this method is sub-standard. Thus this procedure in not being adopted as the worth of the end product is extremely unfavourable, for example, biofuels. Still gravity sedimentation ought to be chosen for microalgal collecting when the thickness of the system is sustanaibily high with high moisture.

\section{Flotation}

Flotation is a gravity separation method in which air or gas bubbles are attached to solid particles and afterward convey them to the fluid surface. Chen et al., (1998). This process is being regarded as an more captivating and economic way to harvest microalgae by utilising their ordinary characteristics of low thickness and self buoyancy. The accomplishment of flotation relies upon the inconstancy of the suspended particles which should be lower then the unsteadiness of the higher air particle contact. Flotation assisted by coagulation can contribute to powerful segregation of micro-algae from the low concentrated medium.other strong points of flotation are low space prerequisites, moderately short time for harvesting and high adaptability with lower prior apparatus costs.

\section{Filtration and screening}

Filtration has been found acceptable at recovering tolerably tremendous algal cells in this method various sorts of filters have been used to assemble micro-algae and regardless of this it is hampered by low throughput and rapid obstruction.

The process of filtration through these filters are mainly beneficial when there is a requirement to keep the bunches of microalgae separated, and when expansive washing is required. However the process of filtration can be hindered by both (A) high microalgal concentration - It can bring blockage in the screen, (b) a low microalgal concentration- it can bring about negligent incarcerate (Wilde et al., 1991).

Membrane filtration has points of interest that incorporate being ecologically inviting as well as supplying isolated water and supplements that can be reused to develop microalgae; thus it allows for a constant cycle utilizing low energy and additionally is being carried out on a low working expensesin contrasted with alternative cycles, for example, centrifugation and flocculation whereas, Screening incorporates giving the suspension through a screen with a particular pore size there are two screening instruments essentially Microstrainer and vibrating screen channels. 


\section{Table.1}

\begin{tabular}{|l|l|l|}
\hline Open ponds & Parameters & Photo bioreactors \\
\hline More & Space required & Less \\
\hline Very high & Loss of water in evaporation & Low \\
\hline Low & Set up cost & High \\
\hline Low & Maintenance cost & High \\
\hline Extremely high & Risk of contamination & Low \\
\hline Less amount required & Energy requirement & large amount required \\
\hline Difficult & $\begin{array}{l}\text { Process control that is control of } \\
\text { ph, temperature }\end{array}$ & Easy \\
\hline Low & $\begin{array}{l}\text { Bio mass quality } \\
\text { Volumetric production } \\
\text { (kg m-1 d-3) }\end{array}$ & \begin{tabular}{l} 
High \\
\hline $\mathbf{9 9 . 4}$
\end{tabular} \\
$\begin{array}{l}\text { Oil yield } \\
\text { (m3 ha-1) } \\
\text { Based on 70\%by wt oil in biomass }\end{array}$ & 1.535 \\
\hline
\end{tabular}

Fig.1 Various stages of biofuel production

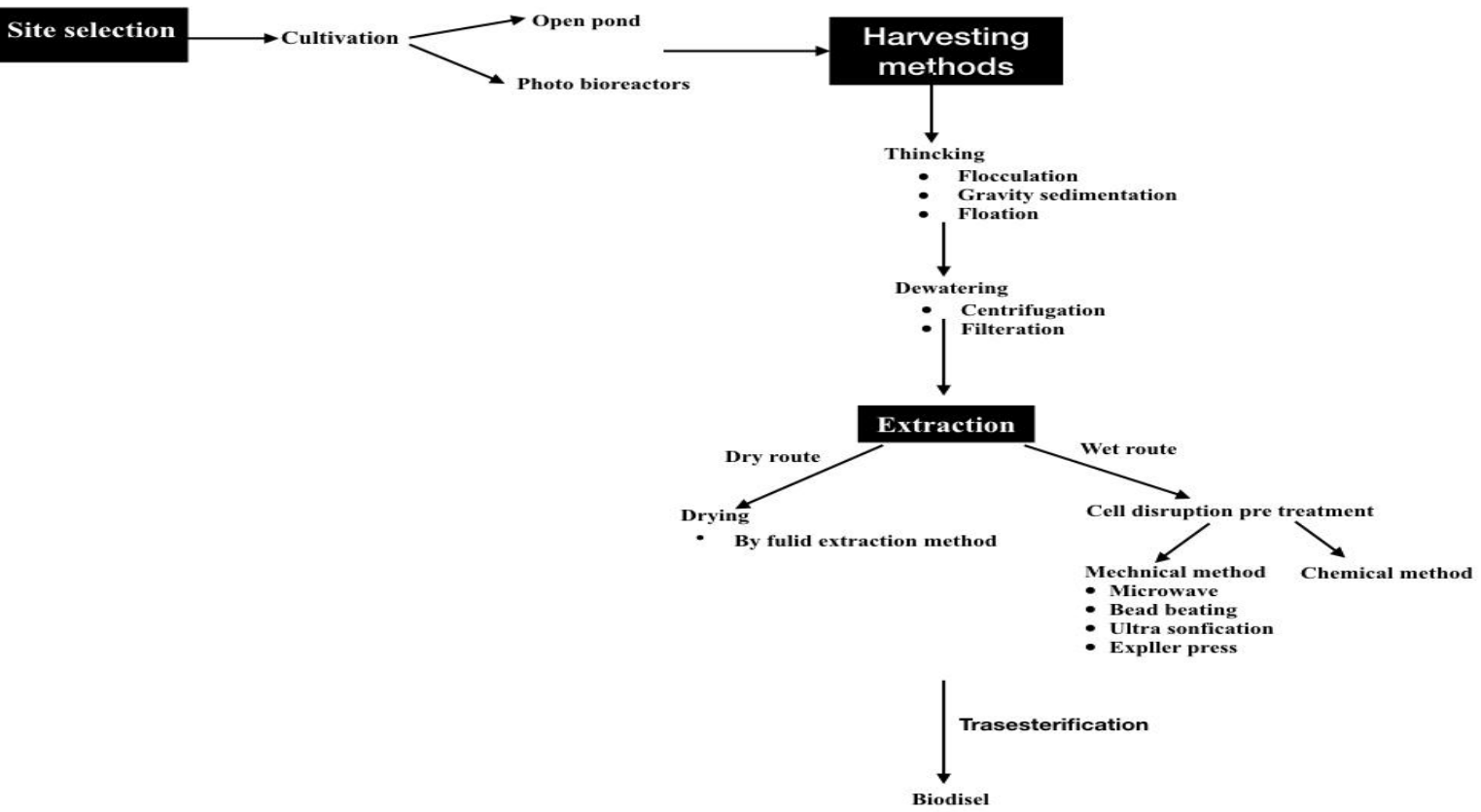


Table.2

\begin{tabular}{|c|c|c|c|c|c|c|}
\hline Microalage & $\begin{array}{l}\text { Marine } \\
\text { or fresh }\end{array}$ & $\begin{array}{l}\text { Culture } \\
\text { condition }\end{array}$ & $\begin{array}{l}\text { Lipid } \\
\text { content (\% } \\
\text { dry weight } \\
\text { biomass) }\end{array}$ & $\begin{array}{l}\text { Biomass } \\
\text { productivity }\end{array}$ & $\begin{array}{l}\text { Lipid } \\
\text { producti } \\
\text { vity }\end{array}$ & Reference \\
\hline Chlorella vulgaris & Both & & $5.0-58.0$ & $0.02-0.20$ & $11.2-40.0$ & \\
\hline $\begin{array}{ll}\text { Chlorella } & \text { vulgaris } \\
\text { Beijerinck CCAP 211/11B }\end{array}$ & Both & Phototrophica & $18.0-40.0$ & $0.03-0.04$ & $5.4-14.9$ & $\begin{array}{l}\text { Illman et } \\
\text { al. }(2000) \\
\text { D }\end{array}$ \\
\hline Chlorella protothecoides & & Heterotrophic & $43.0-46.0$ & $4.0-4.4$ & $\begin{array}{l}1881.3- \\
1840.0\end{array}$ & $\begin{array}{l}\text { Cheng et al. } \\
\text { (2009) }\end{array}$ \\
\hline Chlorella protothecoides & & Heterotrophic & $50.3-57.8$ & $2.2-7.4$ & $\begin{array}{l}1209.6- \\
3701.1\end{array}$ & $\begin{array}{l}\text { Xiong et } \\
\text { al. (2008) }\end{array}$ \\
\hline Chlorella protothecoides & & Heterotrophic & 46.1 & 2.0 & 932.0 & $\begin{array}{l}\mathrm{Xu} \text { et al. } \\
(2006)\end{array}$ \\
\hline Dunaliellasalina & Marine & & $6.0-25.0$ & $0.22-0.34$ & 116.0 & \\
\hline Spirulina platensis & Fresh & Phototropic & $4-16$ & $0.6-4$ & & \\
\hline Nannochloropsis sp & Marine & Phototrophica & 29.2 & 0.17 & 49.7 & $\begin{array}{l}\text { Rodolfi et } \\
\text { al. (2009) }\end{array}$ \\
\hline Neochloris & Fresh & Phototrophica,b & $15.9-56.0$ & $29-65$ & $10.7-38.8$ & $\begin{array}{l}\text { Gouveia et } \\
\text { al. (2009) }\end{array}$ \\
\hline Skeletonema sp. & Marine & Phototrophica & 31.8 & 0.09 & 27.3 & $\begin{array}{l}\text { Rodolfi et } \\
\text { al. (2009) }\end{array}$ \\
\hline Dunaliella tertiolecta & Marine & Phototrophicb & 16.7 & 0.12 & 20.0 & $\begin{array}{l}\text { Gouveia and } \\
\text { Oliveira } \\
\text { (2009) }\end{array}$ \\
\hline Botryococcus braunii & Fresh & Phototrophica & 20.8 & 0.03 & 5.5 & $\begin{array}{l}\text { Yoo et al. } \\
(2010)\end{array}$ \\
\hline Isochrysis sp. & Marine & Phototrophica & 22.4 & 0.17 & 37.7 & $\begin{array}{l}\text { Rodolfi et } \\
\text { al. (2009) }\end{array}$ \\
\hline Pavlova salina & Marine & Phototrophic & 30.9 & 0.16 & 49.4 & $\begin{array}{l}\text { Rodolfi et } \\
\text { al. (2009) }\end{array}$ \\
\hline Pavlova luther & Marine & Phototrophic & 35.4 & 0.14 & 50.2 & $\begin{array}{l}\text { Rodolfi et } \\
\text { al. (2009) }\end{array}$ \\
\hline Tetraselmis suecica & Marine & Phototrophic & 8.5 & 0.32 & 27.0 & $\begin{array}{l}\text { Rodolfi et } \\
\text { al. (2009) }\end{array}$ \\
\hline Scenedesmus obliquus & Fresh & Mixotrpic & $6.6-11.8$ & $0.10-0.51$ & $11.6-58.6$ & $\begin{array}{l}\text { Mandal and } \\
\text { Mallick } \\
\text { (2009) }\end{array}$ \\
\hline $\begin{array}{l}\text { Scenedesmus } \\
\text { quadricauda }\end{array}$ & Fresh & Phototrophic & 18.4 & 0.19 & 35.1 & $\begin{array}{l}\text { Rodolfi et } \\
\text { al. (2009) }\end{array}$ \\
\hline Chlorococcum sp. & Fresh & Phototrophic & 19.3 & 0.28 & 53.7 & $\begin{array}{l}\text { Rodolfi et } \\
\text { al. (2009) }\end{array}$ \\
\hline
\end{tabular}

Extraction of micro-algae

This lipid extraction is considered as one of the most significant approach for separating biodiesel from micro-algae.

Principally the extraction of lipids from the algal sources has been separated into two 
significant parts

A -Lipid extraction by chemicals and solvents.

B -Lipid extraction by a mechanical process.

\section{Lipid extraction by chemical process}

In chemical solvent lipid extraction here are two broadly utilized conventional solvent extraction techniques, in particular, Folch strategy, and Bligh and Dyer technique.

\section{Floch technique}

Folch method applies the use of chloroformmethanol in the volume ratio of 2:1 separately for the extraction of lipids from the biomass, and this method balances the homogenized cells with one-fourth volume of saline arrangement (Folch et al., 1957). Once the test sample was introduced to the solvent, the entire combination was presented to delicate agitation for around $20-25 \mathrm{~min}$ thereafter accompanied by centrifugation at $2000 \mathrm{rpm}$ or by filtration with a filter paper to recuperate the fluid phase.

\section{Bligh an dyer technique}

Bligh and Dyer strategy is driven using 1:2 (volume/volume) chloroform and methanol respectively (Bligh and Dyer, 1959). The Bligh and Dyer extraction technique has been directed in enormous scope measures which empower lipid extraction (Breil et al., 2017).

\section{Lipid extraction by mechanical process}

\section{Microwave}

The microwave extraction was first exhibited by Ganzler at. $2450 \mathrm{MHz}$ frequency it is used in microwave. This frequency of microwave is likewise utilized in cell disturbance since,
$2450 \mathrm{MHz}$ frequency can turn the dipole of $\mathrm{OH}$ bonds in water or alcohol. Microwave radiation is favorable because of its swift entrance into biomass, which brings about instantaneous cell interruption. Inspite of various advantages, there are considerable number of disadvantages. As it requires an immense cooling framework because of the high temperature and pressure used, moreover the thermally labile products will exhaust a huge amount of electricity and then will show degradation.

\section{Ultrasonication}

In this method of extraction, microscopic bubbles are formed in the fluid that is exposed to extension and pressure during rarefaction and compression stages individually. Then the Cell leads to disruption with concurrent arrival of gigantic warmth, pressure, and shear stress that takes place just after compression. The major advantage of ultrasonication method is the accomplishment of strong cell disruption dependent on the cavitation effect. Despite there are certain drawbacks. The energy utilization is high because of the high ultrasonic force and substantial cooling, and it is intricate to escalate this cycle since cavitation just happens in small regions close to ultrasonic tests.

\section{Expeller press}

In the method of expeller press the micro algae is initially dried. this technique is considered as one of the most established strategy for extraction. The mechanism of working of expeller press is in the following manner; A screw type machine was used which presses the dried biomass. Then dried biomass is made to entered through one side and the product was exited from the other side of the press. The persistent pressure and friction are required for compressing the algae dried biomass. 


\section{Bead beating}

This method is also called as bead mill or ball mill is a basic cell interruption procedure that breaks cells by shaking a shut compartment loaded up with the target cells and beads made of quartz or metal. The cells are impeded by collision or friction with the beads. there are varied characteristics that will influence the productivity of bead beating, like the shape of the container, the shaking rate, the size of the bead taken, the number of beads put to use and the types of beads, in addition to this these components will not only impact the cell disruption proficiency but as well as the energy consumption.

\section{Electroporation}

Electroporation is defined as the disarrangement of particles on the cell envelope with dipole moments by applying an electromagnetic field (EF) to the biomass. The technique of electroporation is effective to extract larger proportion of lipid from the algal biomass, the absolute lipid that was extricated in a solitary electroporation treatment was around $92 \%$ while in the other techniques the absolute lipid gain was observed around just 62\%, which is about $20 \%$ less then the electroporation technique.

\section{Challenges of biofuel production}

The first primary challenge faced in the production of micro algae is its intricate process. As It delve into few stages, beginning from the cultivation, harvesting, cell drying, disruption of cell, in the end lipid extraction for biodiesel production. Moreover there are significant expense related with the machinery, working, and maintenance of cultivation system for oil production.

On top of that development of biofuel requests ideal ecological conditions for the growth of micro algae in particular, appropriate light, temperature, nutrients and $\mathrm{pH}$. In fact, providing natural stress can might expand biofuel production, but on expense of diminished biomass yield. It is necessary to maintain the harmony between biomass accumulation and biofuel productivity. As per Patil et al., the greatest expense originates from different specialise machines included between the harvesting and transformation of oil into biofuel.

The next key hindrances in utilizing microalgae as a biofuels is using it within the bounds of the commercial cost where the lipid production requires low cost and with a balance of energy. At present, the expense of creating microalgae biofuel ought to be diminished to multiple times so as to contend with the cost of raw petroleum in the worldwide market. Thus, there is a solid need to recognize and create advanced equipped methods for reaping microalgae with a set objective of the cost at less US $\$ 0.013 /$ gallon of gasoline equivalent (GGE) at a production pace of 0.1 to $1 \mathrm{~m} 3$ of micro algae water/hour. At present it is as yet troublesome and difficult for biofuel to be successfully available over non-renewable energy source.

Nonetheless, it ought to be recognized that a billion gallons of microalgae biofuel production would burn-through a lot of water, energy, and nutrients. So if the supplements are not reused back to the soil in forming a billion gallons of microalgae biofuels, it will requires millions tons of nitrogen and phosphorus consistently. Additionally, the major difficulty lies up in building up the ideal methods to choose the best strains of microalgae for cultivating, harvesting and extracting the oil and ultimately processing into fuel. Hence more research is needed for strain improvement in micro-algal species. There is a gigantic difference in the present methodology that is ought to be filled to 
assure the progress of sustainable and environment friendly energy from microalgae. Regardless it is vital to investigate the maximum possible potential of microalgae, the efficiency in production and the production cost of different microalgae biofuel systems.

In conclusion as persistently the energy requirements of the world are multiplying, which is a regularly depleting the non renewable sources of energy. That is causing a hazardous impact on environment. To eliminate effect it is crucial to exploit third generation biofuel with utmost commerciality.

Improvising downstream and upstream processes might resolve the cost issues: (1) in upstream processing, profoundly profitable strains should be acquired by strain choice, genetic and metabolic engineering, and (2) downstream processing, in which enhanced biofuels yields are procured by improving the cell lipid content and by innovatory conversion of microalgal biomass to biofuels It is also recommended that biofuel production might be joined with nitrogenrich, municipal sludge water and $\mathrm{CO} 2$-rich fuel gas treatment to make it more feasible and commercial. These changes will help is most effective bio fuel production.

\section{References}

Barkia, Ines, Nazamid Saari, and Schonna R. Manning. "Microalgae for high-value products towards human health and nutrition." Marine drugs 17.5 (2019): 304.

Barros, Ana I., et al., "Harvesting techniques applied to microalgae: a review." Renewable and sustainable energy reviews 41 (2015): 1489-1500.

Bharathiraja B, Chakravarthy M, Kumar RR, Yogendran D, Yuvaraj D, Jayamuthunagai $\mathrm{J}$, et al., Aquatic biomass (algae) as a future feed stock for bio-refineries: a review on cultivation, processing and products. Renew Sustain Energy Rev 2015;47:634-53.

Borowitzka MA, Moheimani NR. Sustainable biofuels from algae. Mitig Adapt Strat Gl 2013;18: 13-25.

Branyikova, Irena, et al., "Harvesting of microalgae by flocculation." Fermentation 4.4 (2018): 93.

Bungay HR. Confessions of a bioenergy advocate. Trends Biotechnol 2004;22 (2):67-71.

Chen, Chun-Yen, et al., "Cultivation, photobioreactor design and harvesting of microalgae for biodiesel production: a critical review." Bioresource technology 102.1 (2011): 71-81.

Chisti Y, Yan J. Energy from algae: Current status and future trends. Algal biofuels A status report. Appl Energy 2011;88:3277-3279.

Cheng, Y., Zhou, W.G., Gao, C.F., Lan, K., Gao, Y., Wu, Q.Y., 2009. Biodiesel production from Jerusalem artichoke (Helianthus Tuberosus L.) tuber by heterotrophic microalgae Chlorella protothecoides. J. Chem. Technol. Biotechnol. 84, 777-781.

Dragone, Giuliano, et al., "Third generation biofuels from microalgae." (2010).

Enamala, Manoj Kumar, et al., "Production of biofuels from microalgae-A review on cultivation, harvesting, lipid extraction, and numerous applications of microalgae." Renewable and Sustainable Energy Reviews 94 (2018): 49-68.

Chen, F. and M. R. Johns, "Effect of C/N ratio and aeration on the fatty acid composition of heterotrophic Chlorella sorokiniana," Journal of Applied Phycology, vol. 3, no. 3, pp. 203-209, 1991

Folch J, Lees M, Sloane Stanley Gh. A simple 
method for the isolation and purification of total lipides from animal tissues. J Biol Chem 1957;226:497509.

http://dx.doi.org/10.1371/journal.pone.002051 0.

Garrido-Cardenas, Jose Antonio, et al., "Microalgae research worldwide." Algal research 35 (2018): 50-60.

Gouveia L, Oliveira AC. Microalgae as a raw material for biofuels production. J Ind Microbiol Biot 2009;36:269-274.

Huber GW, Iborra S, Corma A. Synthesis of transportation fuels from biomass: chemistry, catalysts, and engineering. Chem Rev 2006; 106:4044-98.

J.E. Pardo, E. Fernández, M. Rubio, A. Alvarruiz, G.L. Alonso, Characterization of grape seed oil from different grape varieties (Vitis vinifera), Eur. J. Lipid Sci. Technol. 111 (2009) 188-193, http://dx.doi.org/10.1002/ejlt.20080005 2.

Khan MD, Khan N, Nizami AS, Rehan M, et $a l$., Effect of Co-Substrates on Biogas Production and Anaerobic Decomposition ofPentachlorophenol. Bioresour Technol 2017;238:492-501.

Kim, Jungmin, et al., "Methods of downstream processing for the production of biodiesel from microalgae." Biotechnology advances 31.6 (2013): 862-876.

Kumar, SP Jeevan, et al., "Sustainable green solvents and techniques for lipid extraction from microalgae: A review." Algal Research 21 (2017): 138-147.

Lardon, Laurent, et al., "Life-cycle assessment of biodiesel production from microalgae." (2009): 6475-6481.

L. Benov, J. Al-Abraheem, Disrupting Escherichia coli: a comparison of methods, J. Biochem. Mol. Biol. 35 (4) (2002) 428-431.

$\mathrm{Li}$, Mark Horsman Yanqun, Nan $\mathrm{Wu}$, and
Christopher Q. Lan. "Nathalie DuboisCalero Articles: Biocatalysts and bioreactor design: biofuels from Microalgae." Biotechnol Prog 24 (2008): 815-820.

M. A. Borowitzka, "Commercial production of microalgae: ponds, tanks, tubes and fermenters," Journal of Biotechnology, vol. 70, no. 1-3, pp. 313-321, 1999

Mata, Teresa M., Antonio A. Martins, and Nidia S. Caetano. "Microalgae for biodiesel production and other applications: a review." Renewable and sustainable energy reviews 14.1 (2010): 217-232.

Medipally, Srikanth Reddy, et al., "Microalgae as sustainable renewable energy feedstock for biofuel production." BioMed research international 2015 (2015).

Milledge, John J., and Sonia Heaven. "A review of the harvesting of micro-algae for biofuel production." Reviews in Environmental Science and Bio/Technology 12.2 (2013): 165-178.

Miandad R, Nizami AS, Rehan M, Barakat $\mathrm{M}$, et al., Influence of temperature and reaction time on the conversion of polystyrene waste topyrolysis liquid oil. Waste Management 2016;58: 250-259.

Nigam PS, Singh A. Production of liquid biofuels from renewable resources. Prog Energy Combust Sci 2011;37:5268.

Noraini MY, Ong HC, Badrul MJ, Chong WT. A review on potential enzymatic reaction for biofuel production from algae. Renew Sustain Energy Rev 2014;39:24-34.

Ouda OKM, Raza SA, Nizami AS, Rehan M, Al-Waked R, Korres NE. Waste to energy potential: a case study of Saudi Arabia. Renew Sust Energ Rev 2016;61:328-340.

Pandey, Ashutosh, Sameer Srivastava, and Sanjay Kumar. "Development and cost- 
benefit analysis of a novel process for biofuel production from microalgae using pre-treated high-strength fresh cheese whey wastewater." Environmental Science and Pollution Research (2020): 1-18.

Patil V, Tran KQ, Giselrød HR. Towards sustainable production of bio-fuels from microalgae. Int J Mol Sci 2008;9:11881195.

Peng, Licheng, et al., "Biofuel production from microalgae: a review." Environmental Chemistry Letters (2020): 1-13.

Pienkos PT, Darzins A. The promise and challenges of microalgal-derived biofuels. Biofuel Bioprod Bior 2009;3:431-440.

Qari, Huda, Mohammad Rehan, and AbdulSattar Nizami. "Key issues in microalgae biofuels: a short review." Energy Procedia 142 (2017): 898-903.

Qin, Song, Hanzhi Lin, and Peng Jiang. "Advances in genetic engineering of marine algae." Biotechnology Advances 30.6 (2012): 1602-1613.

Rahmanian N, Ali SHB, Homayoonfard M, Ali NJ, et al., Analysis of physiochemical parameters to evaluate the drinking water quality in theState of Perak, Malaysia. Journal of Chemistry, vol. 2015, Article ID 716125, 1-10.

Richmond A. Handbook of microalgal culture: biotechnology and applied phycology. Blackwell Science Ltd; 2004

Richmond A. Biological principles of mass cultivation. Handbook of Microalgal Culture: Biotechnology and Applied Phycology. 2004. p. 125-77.

Rizwan, Muhammad, et al., "Exploring the potential of microalgae for new biotechnology applications and beyond: a review." Renewable and Sustainable Energy Reviews 92 (2018): 394-404.

Sambusiti C, Bellucci M, Zabaniotou A,
Beneduce L, Monlau F. Algae as promising feedstocks for fermentative biohydrogen production according to a biorefinery approach: a comprehensive review. Renew Sustain Energy Rev 2015;44:20-36.

Sanyano, N.; Chetpattananondh, P.; Chongkhong, S. Coagulationflocculation of marine Chlorella sp for biodiesel production. Bioresour. Technol. 2013, 147, 471-476. [CrossRef] [PubMed]

Sheehan, J.; Dunahay, T.; Benemann, J.; Roessler, P. A look back at the US department of energy's aquatic species programsbiodiesel from algae; National Renewable Energy Laboratory (NREL), 1998.

Shelef, G., A. Sukenik, and M. Green. Microalgae harvesting and processing: a literature review. No. SERI/STR-2312396. Technion Research and Development Foundation Ltd., Haifa (Israel), 1984.

Singh A, Nigam PS, Murphy JD. Mechanism and challenges in commercialisation of algal biofuels. Bioresour Technol 2011;102:26-34.

Singh A, Nigam PS, Murphy JD. Renewable fuels from algae: an answer to debatable land based fuels. Bioresour Technol 2011;102:10-6.

Raslavicius L, Semenov VG, Chernova NI, Kersys A, Kopeyka AK. Producing transportation fuels from algae: in search of synergy. Renew Sustain Energy Rev 2014;40:133-42.

Ross AB, Biller P, Kubacki ML, Lea-Langton A, Jones JM. Hydrothermal processing of microalgae using alkali and organic acids. Fuel 2010;89:2234-43.

Slade, Raphael, and Ausilio Bauen. "Microalgae cultivation for biofuels: cost, energy balance, environmental impacts and future prospects." Biomass and bioenergy 53 (2013): 29-38. 
Spolaore P, Joannis-Cassan C, Duran E, Isambert A. Commercial applications of microalgae. Journal of Bioscience and Bioengineering 2006;101(2): 87-96.

Susanto, H., et al., "Performance Evaluation of Flocculation and Membrane Filtration for Microalgae Harvesting." Pertanika Journal of Science \& Technology 25.4 (2017).

Ullah K, Ahmad M, Sofia Sharma VK, Lu P, Harvey A, Zafar M, et al., Assessing the potential of algal biomass opportunities for bioenergy industry: a review. Fuel 2015;143:414-23.

Vassilev, Stanislav V., and Christina G. Vassileva. "Composition, properties and challenges of algae biomass for biofuel application: an overview." Fuel 181 (2016): 1-33.

Veeramuthu, Ashokkumar, and Chawalit
Ngamcharussrivichai. "Potential of Microalgal Biodiesel: Challenges and Applications." Renewable Energy. IntechOpen, 2020.

Xia, Ling, et al., "Effective harvesting of microalgae by coagulation-flotation." Royal Society open science 4.11 (2017): 170867.

Zenouzi, A., et al., "Harvesting of microalgae Dunaliella salina using electroflocculation." (2013): 879-887.

Zidansek A, Blinc R, Jeglic A, Kabashi S, Bekteshi S, Slaus I. Climate changes, biofuels and the sustainable future. Int $\mathrm{J}$ Hydrogen Energy 2009;34:6980-3.

Ziolkowska JR, Simon L. Recent developments and prospects for algaebased fuels in the US. Renew Sustain Energy Rev 2014;29:847-53

\section{How to cite this article:}

Isha Bhansali, Hardik Pathak and Jebi Sudan. 2021. Potential of Micro-algae in Future Biofuels. Int.J.Curr.Microbiol.App.Sci. 10(01): 1568-1580. doi: https://doi.org/10.20546/ijcmas.2021.1001.183 